\title{
Comparing Study on Smart City Strategies in Berlin and Shanghai
}

\author{
Lucie Reiber \\ Sino-German School for Postgraduate Studies (CDHK) \\ Tongji University \\ Shanghai, China \\ lucie.reiber@tongji.edu.cn
}

\author{
Guanwei Huang* \\ Sino-German School for Postgraduate Studies (CDHK) \\ Tongji University \\ Shanghai, China \\ guanwei.huang@tongji.edu.cn
}

\begin{abstract}
Within the framework of this paper the classical approach of strategic management theory shifts its thematic focus from business organizations towards an even more complex system, namely that of cities. As a significant example of urban development approaches, the smart city model has gained large attention by policy makers around the world. In the early $2010 \mathrm{~s}$, both, Shanghai and Berlin, implemented their own smart city strategies with the aim of establishing themselves as the leading smart city within their country or even continent. Basing on a multi-case study approach by linking inductive (data-driven) and deductive (theory-driven) methods iteratively, a universal smart city model is developed. Secondly, a quantitative index evaluating the smartness of the case cities is created and applied. Considering the results of the smart city index, the German capital scores higher, but regarding the priorities of the smart city strategies, Shanghai outperforms Berlin. It can be concluded that a top-down approach, as applied in Shanghai, leads to higher scores in smartness if the city's priorities are considered. A hybrid form, as applied in Berlin, leads to a better ranking in general smartness.
\end{abstract}

Keywords-Smart city; Open data; Smart community; Case study; Measurement method; Smart city index

\section{INTRODUCTION}

According to the United Nations in 2008, for the first time in history, the majority of people worldwide lived in urban areas [1]. With cities as the major consumer of resources [2] this global trend of urbanization underlines the social, economic and ecological significance of urban areas $[3,4]$ and their challenges including limited resources, lack of space, demand for jobs, water, soil and air pollution, and waste disposal $[3,5,6]$.

On the one hand, metropolitan areas are a major cause of the 21st century's dilemmas; on the other hand, they are also recognized as the key sites for solving these problems $[7,8,9]$. Accordingly, this assumption gave rise to an amount of urban development approaches accompanied by various policy recommendations. Here, the concept of the smart city, described as being "on the cutting edge of urban innovation" [8], is seen as a significant example that is predicted to retain its popular status among policy makers and urban planners in the future $[5,10,11]$.

\footnotetext{
*Corresponding author: Guanwei Huang, guanwei.huang@tongji.edu.cn
}

Despite its prominence among urban policy makers around the globe, a universal characterization of the smart city concept is absent $[11,12,13]$. This paper succeeds with the working definition by the European Parliament: "A smart city is a city seeking to address public issues via ICT-based solutions on the basis of a multi-stakeholder municipally based partnership" [12]. Here, smart technologies act as a translating instrument in a complex adaptive and viable system linking collective needs to city services and infrastructures in a more effective, efficient and sustainable way $[14,15,16]$.

\section{Methodology}

The theoretical foundation of this paper is formed by an integrated in-depth literature review through gathering an initial set of literature and proceeding with the method of backward snowballing [17]. On this knowledge basis, the two case cities, Berlin and Shanghai, are analyzed since both have planned and initiated smart city strategies in the recent past years $[18,19,20]$. Information about the two cases was collected through publicly available secondary data including city-specific urban planning documents, media reports and academic papers. By the comparison of the two smart city concepts, characteristics of a general smart city model are identified inductively.

The second part of the study is focusing on the creation and application of a smart city index. This evaluation method proceeds with the structure and dimensions of the prior created smart city model. Thereafter, measurable indicators are assigned to the corresponding factors deductively. Subsequently, quantifiable information about the smartness of the two case cities is received by using two different weighting methods and three data set versions. Accordingly, this multicase study $[21,22]$ uses cross-case analysis linking deductive and inductive approaches iteratively [23].

\section{RESULTS}

\section{A. Smart City Model}

Regarding the two case cities' strategies, the Chinese metropolis is relying on a top-down approach [20], whereas a hybrid form with a bottom-up character is applied in the German capital [24]. Despite these different implementation methods, several similarities and patterns of smart city strategies are identified. It becomes apparent that all Giffinger et al.'s six dimensions smart governance, economy, 
environment, mobility, living and people [25], are applied in the real case examples $[20,26]$. Consequently, they coincide with the dimensions of this paper. Additionally, both theory and empiricism emphasize the essential role played by information and communications technology [13,18,19,20]. Thus, the core position of the ICT infrastructure is visualized within the smart city model. Furthermore, a subdivision of the factors into an inner smart-technology-based and an outer related ring is undertaken. Taking Giffinger et al.'s 33 smart city factors [25] into account, while adding the components smart city strategy (smart governance), smart card (smart environment) and public safety (smart living), leads to eleven inner and six outer smart city factors, as seen in Fig.1.

Whether a factor is included in the inner circle is merely determined by the role played by information and communications technology within each factor. Only if components of ICT infrastructure, as sensors, apps or platforms etc. [27] are actively involved within a factor, it is included in the inner ring. A strong relation to a smart city issue but with an absence of specific smart technology leads to the assignment of the component to the outer ring.

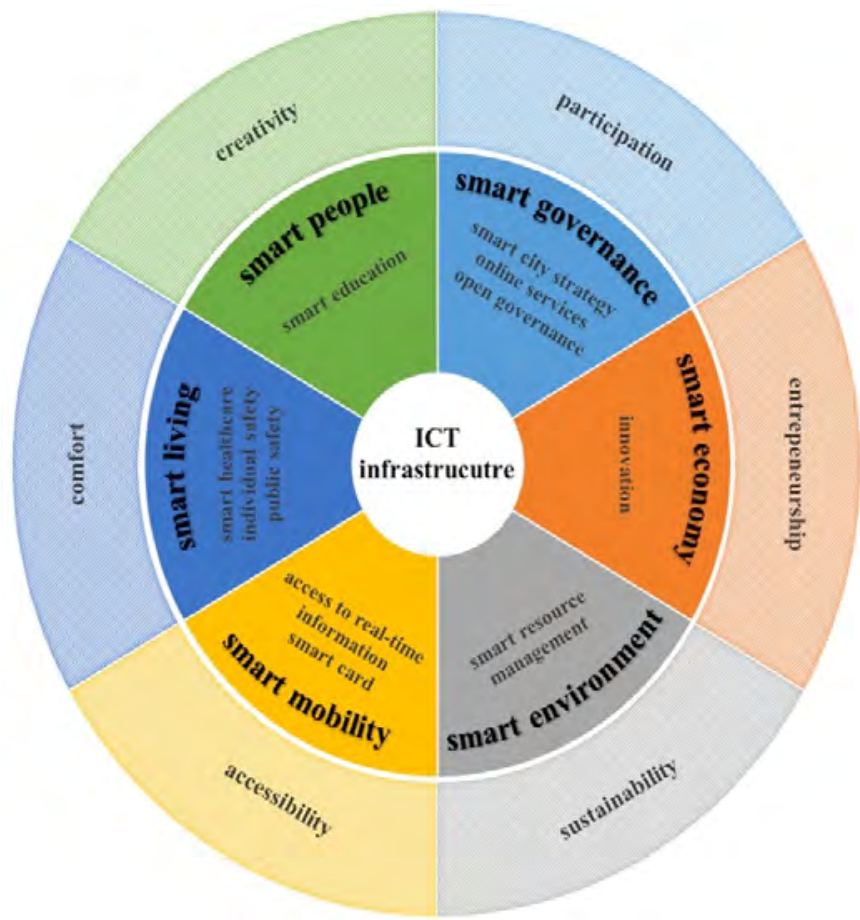

Fig. 1. Smart City Model

\section{B. Smart City Index}

In total 29 indicators [25,28,29] (see Table I ) are assigned to the ICT core and to the six smart city dimensions creating a quantitative index framework to evaluate the smartness of the case cities. As the outer factors demonstrate a strong relation to the smart city subject, but do not represent smart city components themselves, it is not intended to apply the outer indicators in the index framework.

If no information about an indicator was available, the missing data is replaced by imputation with regression substitution assuming that data is missing at random. In some cases, it is assumed that the unavailability of data about a certain smart city component is caused by the lack of its existence. Overall, two weighting methods and three data set versions are applied. While version 1 is characterized by the highest level of uncertainty due relying on a higher number of assumptions, version 2 (excluding assumed values) and 3 (excluding values $\mathrm{Df} \neq[0 ; 1]$ ) originate from a smaller sample sizes. Weighting method A weights the seven dimensions equally, as in (1), whereas variation B takes the priorities of the respective smart city strategies into account. The priorities (wi) are measured by the proportional number of smart city projects assigned to the seven dimensions respectively, as shown in (2).

$$
\begin{aligned}
& S C I_{1.4}=\frac{1}{7} \sum_{k=1}^{7}\left[\frac{1}{6} \sum_{i=1}^{6} g o v_{i}+\frac{1}{3} \sum_{i=1}^{3} e c o n_{i}+\frac{1}{4} \sum_{i=1}^{4} m o b_{i}+\frac{1}{4} \sum_{i=1}^{4} e n v_{i}+\frac{1}{4} \sum_{i=1}^{4} l i v_{i}+\text { peop }+\frac{1}{7} \sum_{i=1}^{7} I C T_{i}\right] \\
& S C I_{1 . B}=\frac{w_{g o v}}{6} \sum_{i=1}^{6} g o v_{i}+\frac{w_{e c o n}}{3} \sum_{i=1}^{3} e c o n_{i}+\frac{w_{m o b}}{4} \sum_{i=1}^{4} m o b_{i}+\frac{w_{e n v}}{4} \sum_{i=1}^{4} e n v_{i}+\frac{w_{l i v}}{4} \sum_{i=1}^{4} l i v_{i}+w_{l i v} \cdot p e o p \\
& +\frac{w_{I C T}}{7} \sum_{i=1}^{7} I C T_{i}
\end{aligned}
$$

Applying (1) (version 1.A) and (2) (version 1.B) on the two case cities and version 2 and 3 accordingly, leads to the results in Table II. The higher score for each combination is highlighted.

Regarding the results of the seven single smart city components, a clear connection between the priorities of the cities to their leading scores is emphasized. Berlin's strengths in smart mobility, environment and ICT become apparent, while Shanghai gets leading results in smart governance, economy and living. Applying equal weighting on each dimension and taking each indicator into account (version 1.A), Berlin receives a higher final smart city index than Shanghai. This also applies if assumed data is left out (version 2.A). Accordingly, Berlin's advantages in ICT, smart mobility, environment and people surpass Shanghai's leading performance in smart governance, economy and living. However, if the dimensions are weighted by the cities' priorities (version 1.B, 2.B and 3.B), the Chinese metropolis takes the leading score. Moreover, just taking proportional data into account, Shanghai outperforms Berlin when applying both weighting methods (version 3.A and 3.B). Considering the smartness of the two cities from an outer perspective, the German capital scores higher, yet, regarding the priorities of the smart city strategies of both cities, Shanghai outperforms Berlin. To categorize the smart city performance levels more generally, more case cities need to be analyzed. 
TABLE I. FACTORS AND INDICATORS ASSIGNED TO SMART CITY DIMENSIONS

\begin{tabular}{|c|c|c|c|}
\hline Dimension & Factor & & Indicator \\
\hline \multirow{6}{*}{ Smart Governance } & $\begin{array}{l}\text { smart city } \\
\text { strategy (SCS) }\end{array}$ & 1 & $\begin{array}{l}\text { one point for each: 1) formal, comprehensive, city-specific SCS, 2) SC organization formed with clearly } \\
\text { defined roles, 3) SCS updated regularly, 4) SC performance criteria clearly defined, 5) active citizens' } \\
\text { participation during SCS definition }\end{array}$ \\
\hline & participation & 2 & Y/N: citywide participation platforms (e.g. complaining platform, ...) existent \\
\hline & online services & 3 & $\%$ of government services online \\
\hline & \multirow{3}{*}{$\begin{array}{l}\text { open } \\
\text { government }\end{array}$} & 4 & Y/N: open data platform available \\
\hline & & 5 & \# mobile apps based on open data \\
\hline & & 6 & Y/N: citywide privacy policy to protect confidential citizen data existent \\
\hline \multirow{3}{*}{ Smart Economy } & \multirow{3}{*}{ innovation } & 7 & \% GDP invested in R\&D \\
\hline & & 8 & \# patent applications per 100.000 inhabitants \& year \\
\hline & & 9 & $\%$ GVA originating from ICT industry \\
\hline \multirow{4}{*}{ Smart Mobility } & \multirow{3}{*}{$\begin{array}{l}\text { access to real- } \\
\text { time information }\end{array}$} & 10 & $\%$ traffic lights connected to real-time traffic management system \\
\hline & & 11 & $\begin{array}{l}\text { one point for each: public transit services offering real-time information to the public: 1) bus, 2) regional } \\
\text { train, 3) metro, 4) rapid transit system (e.g. BRT, tram), 5) car-sharing, 6) bike-sharing, 7) parking lot } \\
\text { management, 8) taxi }\end{array}$ \\
\hline & & 12 & $\begin{array}{l}\text { one point for each: multi-modal transit apps with } 3 \text { services integrated: 1) route planner, 2) real-time data, } \\
\text { 3) tickets }\end{array}$ \\
\hline & smart cards & 13 & $\begin{array}{l}\text { Y/N: unified public transit smart card systems available for bus, regional train, metro, rapid transit system } \\
\text { (e.g. BRT, tram), car-sharing, bike-sharing, taxi }\end{array}$ \\
\hline \multirow{4}{*}{$\begin{array}{l}\text { Smart } \\
\text { Environment }\end{array}$} & \multirow{4}{*}{$\begin{array}{l}\text { smart resource } \\
\text { management }\end{array}$} & 14 & $\%$ commercial \& industrial buildings with smart meters \\
\hline & & 15 & $\%$ private buildings with smart meters \\
\hline & & 16 & $\begin{array}{l}\text { \% coverage municipal grid meeting following requirements: 1) 2-way communication, 2) automated } \\
\text { control systems for addressing system outages, 3) real-time information for costumers, 4) permits } \\
\text { distributed generation, 5) supports net metering }\end{array}$ \\
\hline & & 17 & $\%$ coverage municipal smart waste management \\
\hline \multirow{4}{*}{ Smart Living } & smart healthcare & 18 & $\%$ residents with electronic medical records \\
\hline & individual safety & 19 & $\begin{array}{l}\text { \% smart homes with, one point for each: 1) livestreaming video cameras, 2) information for security } \\
\text { organizations in case of emergency }\end{array}$ \\
\hline & \multirow[t]{2}{*}{ public safety } & 20 & $\begin{array}{l}\text { one point for each: municipal technologies in use to assist with crime prevention: } 1) \text { livestreaming video } \\
\text { cameras }(1 \text { point }=\text { citywide, } 0.5 \text { point }=\text { places of public interest } \& \text { public transport), 2) predictive crime } \\
\text { software technologies }\end{array}$ \\
\hline & & 21 & $\begin{array}{l}\text { \% industrial, commercial \& public buildings with information for security organizations in case of } \\
\text { emergency }\end{array}$ \\
\hline \multirow{2}{*}{ Smart People } & smart education & 22 & $\%$ education institutions that provide smart education services \\
\hline & creativity & & \% labor force in creative industries \\
\hline \multirow{7}{*}{ ICT } & \multirow{5}{*}{$\begin{array}{l}\text { internet } \\
\text { connection }\end{array}$} & 23 & $\%$ households with computers \\
\hline & & 24 & $\%$ residents with smartphones \\
\hline & & 25 & average internet download speed [Mbps] \\
\hline & & 26 & $\%$ households with internet download speed of at least $50 \mathrm{Mbps}$ \\
\hline & & 27 & \# WLAN hotspots per km2 \\
\hline & sensor coverage & 28 & $\begin{array}{l}\text { one point for each: infrastructure components with installed sensors: 1) traffic, 2) public transit demand, 3) } \\
\text { parking, 4) air quality, 5) waste, 6) water, 7) public lighting, 8) weather }\end{array}$ \\
\hline & $\begin{array}{l}\text { integrated public } \\
\text { operations }\end{array}$ & 29 & $\begin{array}{l}\text { one point for each: services integrated in a singular operations center leveraging real-time data: 1) } \\
\text { emergency response, 2) fire, 3) police, 4) ambulance, 5) transit, 6) weather, 7) air quality }\end{array}$ \\
\hline
\end{tabular}

TABLE II.

\section{SMART City INDEX RESUlts: BERLIN AND SHANGHAI}

\begin{tabular}{|c|c|c|c|c|c|c|c|c|}
\hline & \multicolumn{2}{|c|}{ Priorities } & \multicolumn{2}{|c|}{ Version 1} & \multicolumn{2}{|c|}{ Version 2} & \multicolumn{2}{|c|}{ Version 3} \\
\hline & $B E$ & SH & $B E$ & SH & $B E$ & SH & $B E$ & $S H$ \\
\hline $\begin{array}{l}\text { Smart } \\
\text { governance }\end{array}$ & 0.14 & 0.20 & $\begin{array}{l}0.76 \\
5\end{array}$ & $\begin{array}{l}0.91 \\
8\end{array}$ & $\begin{array}{l}0.76 \\
5\end{array}$ & $\begin{array}{l}0.96 \\
0\end{array}$ & $\begin{array}{l}0.74 \\
4\end{array}$ & $\begin{array}{l}0.94 \\
6\end{array}$ \\
\hline Smart economy & 0.16 & 0.28 & $\begin{array}{l}0.63 \\
7\end{array}$ & $\begin{array}{l}0.83 \\
9\end{array}$ & $\begin{array}{l}0.63 \\
7\end{array}$ & $\begin{array}{l}0.83 \\
9\end{array}$ & & \\
\hline Smart mobility & 0.18 & 0.08 & $\begin{array}{l}0.46 \\
9\end{array}$ & $\begin{array}{l}0.23 \\
8\end{array}$ & $\begin{array}{l}0.62 \\
5\end{array}$ & $\begin{array}{l}0.31 \\
7\end{array}$ & $\begin{array}{l}0.62 \\
5\end{array}$ & $\begin{array}{l}0.31 \\
7\end{array}$ \\
\hline $\begin{array}{l}\text { Smart } \\
\text { environment }\end{array}$ & 0.27 & 0.04 & $\begin{array}{l}0.13 \\
4\end{array}$ & $\begin{array}{l}0.10 \\
6\end{array}$ & & & & \\
\hline Smart living & 0.18 & 0.32 & $\begin{array}{l}0.25 \\
0 \\
\end{array}$ & $\begin{array}{l}0.67 \\
3 \\
\end{array}$ & $\begin{array}{l}0.25 \\
0 \\
\end{array}$ & $\begin{array}{l}0.50 \\
0 \\
\end{array}$ & $\begin{array}{l}0.25 \\
0 \\
\end{array}$ & $\begin{array}{l}0.50 \\
0 \\
\end{array}$ \\
\hline Smart people & 0.04 & 0.04 & $\begin{array}{l}1.00 \\
0\end{array}$ & $\begin{array}{l}0.12 \\
1\end{array}$ & $\begin{array}{l}1.00 \\
0\end{array}$ & $\begin{array}{l}0.12 \\
1\end{array}$ & & \\
\hline ICT & 0.04 & 0.04 & $\begin{array}{l}0.68 \\
7 \\
\end{array}$ & $\begin{array}{l}0.54 \\
8\end{array}$ & $\begin{array}{l}0.80 \\
2\end{array}$ & $\begin{array}{l}0.65 \\
7 \\
\end{array}$ & $\begin{array}{l}0.72 \\
8 \\
\end{array}$ & $\begin{array}{l}0.65 \\
6 \\
\end{array}$ \\
\hline Weight-Ing A & - & - & $\frac{0.56}{3}$ & $\begin{array}{l}0.49 \\
2\end{array}$ & $\begin{array}{l}0.68 \\
0\end{array}$ & $\begin{array}{l}0.56 \\
6\end{array}$ & $\begin{array}{l}0.58 \\
7\end{array}$ & $\frac{0.60}{5}$ \\
\hline Weight-Ing B & - & - & $\begin{array}{l}0.46 \\
2\end{array}$ & $\frac{0.66}{9}$ & $\begin{array}{l}0.61 \\
2\end{array}$ & $\frac{0.66}{9}$ & $\begin{array}{l}0.55 \\
2\end{array}$ & $\frac{0.62}{9}$ \\
\hline
\end{tabular}

\section{SUMMARY}

The volatile results clearly demonstrate the variability and limited robustness of the index and accordingly must be treated with caution. Interpretations are just expedient as far as both case cities perform dissimilar within the different dimensions and according to their set priorities. While generally high scores are achieved in smart governance and economy, relatively low performance is shown in the smart environment dimension. Linking the findings of the qualitative comparison to the results of the smart city index, it can be concluded that a top-down approach, as applied in Shanghai, leads to higher scores in smartness if the city's priorities are considered. A hybrid form, as applied in Berlin, leads to a better ranking in general smartness. Consequently, the leadership of a wellorganized urban government with clearly defined, city-specific, comprehensible, measurable and regularly reviewed goals in active dialogue with the city's residents, business and research institutions is essential to implement a smart city strategy successfully. 


\section{ACKNOWLEDGMENT}

This research was academically supported by the Innovation and Information Management Chair of the SinoGerman School for Postgraduate Studies of Tongji University and the Strategic Leadership and Global Management Chair of Technical University Berlin.

\section{REFERENCES}

[1] United Nations, Department of Economic and Social Affairs, World urbanization prospects: The 2007 revision, New York: United Nations, 2008, pp. 1.

[2] United Nations, Department of Economic and Social Affairs, World urbanization prospects: The 2014 revision, highlights, New York: United Nations, 2014, pp. 2-3.

[3] C. Etezadzadeh, Smart city - Future city?: Smart city 2.0 as a livable city and future market, Wiesbaden: Springer, 2016, pp. 1-17.

[4] K. Mori and A. Christodoulou, "Review of sustainability indices and indicators: Towards a new city sustainability index (CSI)," EIA Review, vol. 32, pp. 94-106, January 2012.

[5] M.P. Rodríguez Bolívar, "Smart cities: Big cities, complex governance?" in: M.P Rodríguez Bolívar, Transforming city governments for successful smart cities, vol. 8, Cham: Springer International Publishing, 2015, pp. 1-8.

[6] N.A. Streitz, "Smart cities, ambient intelligence and universal access," in: C. Stephanidis, Universal access in human-computer interaction. Context diversity. UAHCI 2011, Lecture notes in computer science, vol. 6767, Berlin: Springer, 2012, pp. 425-432.

[7] B.J. Barber, If mayors ruled the world. Dysfunctional nations, rising cities, New Haven: Yale University Press, 2013, pp. 4-6.

[8] E.L. Glaeser, Triumph of the city: How our greatest invention makes us richer, smarter, greener, healthier, and happier, New York: Penguin Press, 2011, pp. 7-8.

[9] B. Katz and J. Bradley, The metropolitan revolution: How cities and metros are fixing our broken politics and fragile economy, Washington: Brookings Institution Press, 2013, pp. 12-13.

[10] T. Shelton, M. Zook, and A. Wiig, "The 'actually existing smart city'," Camb. J. Urban Tech. vol. 8, pp. 13-25, March 2015.

[11] V. Albino, U. Berardi, and R.M. Dangelico, "Smart cities: Definitions, dimensions, performance, and initiatives," J. Urban Tech., vol. 22, pp. 3 21, February 2005.

[12] European Parliament, "Mapping smart cities in the EU, European Parliament, Directorate General for internal policies," Brussels, 2014, pp. 21-23.

[13] T. Nam and T.A. Pardo, "Conceptualizing smart city with dimensions of technology, peoples and institutions," in Proc. 12th Annu. Intern. Conf. Digital Government Research, College Park, MD, vol. 1, 2011, pp. $282-$ 291
[14] F. Caputo, B. Buhnova, and L. Walletzky, "Investigating the role of smartness and sustainability: Insights from the smart grid domain," Sustainability Science, vol. 1, pp. 10-11, March 2018.

[15] F. Caputo, L. Walletzky, and P. Stepanek, "Towards a systems thinking based view for the governance of a smart city's ecosystem. A bridge to link smart technologies and big data," Kybernetes, vol. 1, pp. 3-5, May 2018.

[16] M. Saviano, S. Barile, and F. Caputo, "Re-affirming the need for systems thinking in social sciences: A viable systems view of smart city," in S. Vrontis, T. Weber, E. Tsoukatos, Global and national business theories and practice: bridging the past with the future, Cyprus: EuroMed Pres, 2017, pp. 1552-1567.

[17] C. Wohlin, "Guidelines for snowballing in systematic literature studies and a replication in software engineering," in: M. Shepperd, EASE 2014 18th Intern. Conf. Eval. Assessm. Software Eng., London, New York: Assoc. Comp. Machinery, 2014, pp. 1-10.

[18] Senate Department for Urban Development and the Environment, Smart City Strategy Berlin, Berlin: Senate Department for Urban Development and the Environment, 2015, pp. 2-16.

[19] Shanghai Municipal People's Government, "Action plan 2011-2013 of Shanghai Municipality for Building Smart City," http://www.shanghai.gov.cn/shanghai/node27118/node27973/u22ai7089 8. html. Accessed November 11,2016.

[20] Shanghai Government, "Action Plan 2014-2016 of Shanghai Municipality for Building Smart City (in Chinese)," http://www.sheitc.gov.cn/zxgh/665205.htm. Accessed November 3,2016.

[21] H. Mintzberg and J.A. Waters, "Tracking strategy in an entrepreneurial form,” AMJ, vol. 25, pp. 465-499, September 1982.

[22] R.K. Yin, Case study research: Design and methods. 4th edition, Thousand Oaks: Sage, 2009, pp. 4-5.

[23] A. Langley, "Strategies for theorizing from process data," AMR, vol. 24, pp. 691-710, October 1999.

[24] A.C. Erbstößer, Smart City Berlin. Urban technologies for metropoles Report 2014 (in German), Berlin: Technologiestiftung Berlin, 2014, pp. 10-11.

[25] R. Giffinger, C. Fertner, H. Kramar, R. Kalasek, N. Pichler-Milanović, and E. Meijers, Smart cities - Ranking of European medium-sized cities, Final report, Vienna: Centre of Regional Science, 2007, pp. 10-12.

[26] Senate Department for Urban Development and the Environment. Smart City Strategy Berlin. Appendix (in German), Berlin: Senate Department for Urban Development and the Environment, 2015, pp. 2-16.

[27] F. Kresin, "Design rules for smarter cities," in: D. Hemmet, A Townsend, Smart citizens, Manchester: FutureEverything Publications, 2013, pp. 51-54.

[28] B. Cohen, "The smartest cities in the world 2015: Methodology," information on: https://www.fastcoexist.com/3038818/the-smartestcities-in-the-world-2015-methodology. Accessed November 1, 2016.

[29] J.H. Lee, M.G. Hancock, and M.C. Hu, "Towards an effective framework for building smart cities: Lessons from Seoul and San Francisco," Technol. Forecast. Soc. Change, vol. 89, pp. 80-99, November 2014. 